\title{
Entrevista com João Paulo Cuenca
}

\section{Joelma Santana Siqueira (Universidade Federal de Viçosa) Vivaldo Andrade dos Santos (Georgetown University)}

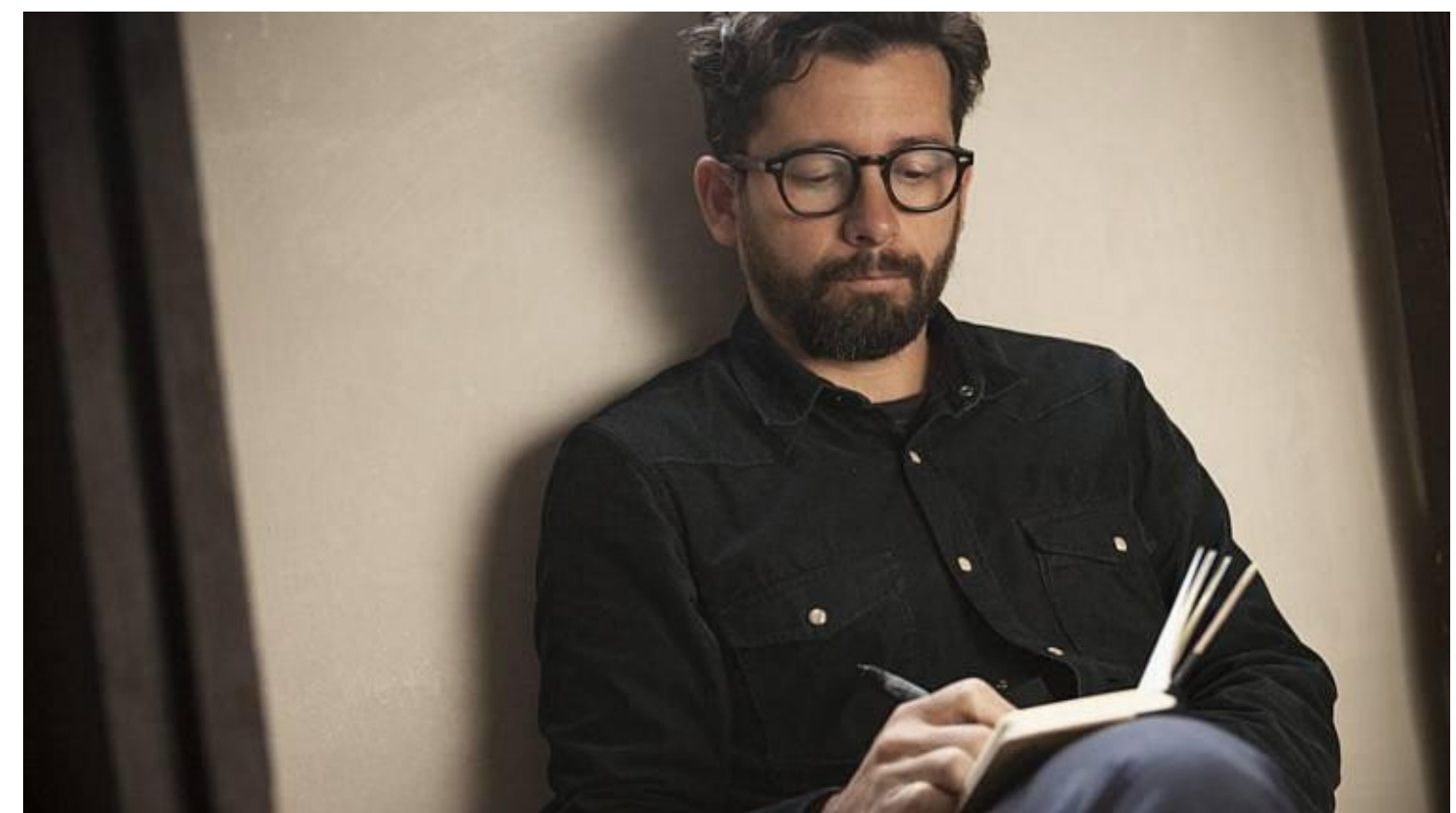

Fonte: New in Oeiras. Disponível em: https://newinoeiras.nit.pt/cultura/o-convidado-desta-edicao-de-lerolhos-nos-olhos-e-joao-paulo-cuenca/.

João Paulo Cuenca é um escritor e cineasta argentino-brasileiro. Autor dos romances Corpo presente (2003), O dia Mastroianni (2007), O único final feliz para uma história de amor é um acidente (2010) e Descobri que estava morto (2016), eleito o melhor romance do ano pelo Prêmio Literário Biblioteca Nacional e finalista do Prêmio Jabuti. Seus livros foram traduzidos para oito idiomas e tiveram os direitos comprados por onze países. Em 2007, foi selecionado pelo Festival de Hay como um dos 39 jovens autores mais destacados da América Latina, e, em 2012, escolhido pela revista britânica Granta como um dos ,20 melhores 
romancistas brasileiros com menos de 40 anos. Desde 2003 escreve crônicas semanais para os principais veículos do país como Tribuna da Imprensa, Jornal do Brasil, O Globo, Folha de S.Paulo, The Intercept Brasil e DW Brasil. Suas crônicas foram reunidas na antologia $A$ última madrugada (2012). Em 2016, dirigiu seu primeiro longa-metragem, A morte de J.P. Cuenca, selecionado para o Festival do Rio e para a Mostra Internacional de Cinema de SP no ano seguinte. O projeto foi escolhido em 2013 para participar do primeiro workshop do Bienalle College - Cinema Project, realizado pela Bienal de Veneza, e ganhou o edital de coprodução da RioFilme com o Canal Brasil no mesmo ano.

1. Prezado João Paulo Cuenca, somos muito gratos a você por nos conceder essa entrevista para o presente dossiê da Gláuks dedicado ao tema "A literatura brasileira no exterior". Para iniciarmos, pedimos que nos fale sobre como é escrever e publicar literatura no Brasil.

Num país pouco alfabetizado e que não valoriza seus escritores, trata-se de atividade de exceção. O escritor brasileiro tem, em seu país, as mesmas dificuldades que um escritor traduzido no resto do mundo. Seus originais estão numa língua que quase ninguém lê.

2. Você considera que há diferenças que mereçam ser destacadas entre a recepção que sua obra tem no Brasil e a que tem no exterior?

Sim. No exterior, tenho a impressão de que a crítica e os comentaristas se atêm mais às marcas textuais. Ou seja: leem mais o livro pelo que ele é. Aqui, há uma tendência maior em partir do contexto social. E, como os escritores brasileiros são mais conhecidos pelos críticos daqui, tenho a impressão de que há uma tendência a ler os autores junto com os seus romances.

Gláuks: Revista de Letras e Artes - jul/dez, 2020 - v. 20, n. 2 
3. Qual a importância da tradução, sobretudo, para o escritor que escreve em português?

Para mim, fundamental. A experiência de acompanhar traduções, fazer a promoção desses livros e acompanhar suas resenhas fez de mim um escritor muito mais atento. Sempre aprendo com esse processo - sobre os livros que escrevo e sobre os que pretendo escrever.

4. Quais são os desafios para ser publicado no exterior ou ser traduzido para outra língua?

A língua portuguesa é periférica, o interesse para o autor brasileiro é ínfimo e programas de apoio à tradução mínguam por aqui.

5. "Traduttore, traditore". Como é ler sua obra traduzida para outro idioma? Destacaria algum exemplo?

É ler um diálogo entre o meu livro, um tradutor e duas línguas. Não acho que estamos no campo da fidelidade aqui.

6. Existe uma "literatura nacional”, presa a um país, a uma região, a uma língua?

Sim, mas acredito que há escritores que fogem completamente a esse tipo de atavismo, como Kafka ou Clarice Lispector. Eu tento navegar entre os dois extremos.

Gláuks: Revista de Letras e Artes - jul/dez 2020 - v. 20, n. 2 
7. Seu fazer literário busca responder a alguma urgência presente na realidade social brasileira que você gostaria de destacar?

Às vezes, sim. Em outras, não. O que move cada projeto são minhas paixões naquele momento. Se no meu último romance há um forte aspecto político, no livro anterior a este, descrevo uma realidade completamente alienígena à nossa, alheio às nossas questões. $\mathrm{O}$ que há em comum é, sempre, escrever sob o Brasil. Se o livro é sobre o país ou não é o que varia. 